\section{The United Nations, Interna- tional Higher Education, and Knowledge Diplomacy}

\section{Nanette Svenson}

Nanette Svenson is an adjunct professor at Tulane University and consultant for the United Nations and other international organizations. More on the UN, higher education and training appears in her book, The United Nations as a Knowledge System. E-mail: nanette.svenson@gmail.com.

$\mathrm{T}$ he term "knowledge diplomacy" has been used with increasing frequency in recent years to describe many things, including how international higher education (IHE) can become an instrument of soft power and a tool through which smaller nations may position themselves to negotiate beyond the parameters of their traditional power base. As the quintessential agent of world diplomacy, the United Nations (UN) should be included in these discussions as they relate to knowledge- even with regard to IHE, though this is not an area typically associated with the UN. Motivated by the furthering of social learning, center-periphery knowledge transfer, research generation and improved public relations, the UN has begun to engage in IHE programming. This article examines the nature of this activity and offers commentary on which aspects of it hold more potential for advancing the goals of the UN and its members.

\section{University Degree Programming}

Much of UN international higher education involvement revolves around university level training and degree granting. The UN has established a number of programs and schools through partnerships with other academic and professional organizations. Their purpose has been to bridge gaps between theory and practice in key areas of global governance and development, and to complement national academic institutions' programming.

The United Nations University (UNU) was established in I972 as a global think tank and postgraduate teaching organization. Headquartered in Tokyo and endowed by the Japanese government, UNU has I6 partner institutes and programs in different countries, that concentrate on issues related to peace and security, human rights, governance, science and technology, and sustainable development. Most UNU work focuses on partner institution research, though in 2012 the university also began to grant Master's degrees. The University for Peace in Costa Rica, founded by the UN General Assembly in I980, grants graduate degrees in disciplines related to peace and security and engages in non- degree programs and research, often collaborating with international partners. The World Maritime University (WMU) is a postgraduate maritime institute in Sweden, founded in 1983 by the International Maritime Organization (IMO), another UN specialized agency. WMU emerged in response to a global shortage of qualified maritime experts, especially in developing nations, and provides various Master's degrees and professional certifications. The IMO also founded the International Maritime Law Institute (IMLI) in Malta in I988 to train international maritime law specialists. IMLI offers graduate degrees, maritime diplomas and various short courses. Similarly, the International Labor Organization International Training Center established the Turin School of Development (TSD) in 2009 to introduce a series of postgraduate programs and courses on international labor legislation and development. TSD is the result of a partnership with the University of Turin, several other schools, and various UN agencies.

\section{Much of UN international higher educa- tion involvement revolves around uni- versity level training and degree grant- ing.}

All these UN university programs have pursued local and international accreditation, attracted multinational faculty and students, and created new degree programs linked to UN knowledge and objectives. Collectively over the past three decades they claim thousands of graduates from countries all over the world and host a range of international conferences, research projects, and academic publications.

\section{Non-degree Programs}

Beyond its university degree granting and research, the UN has pioneered other IHE initiatives that support shorterterm activities and facilitate partnerships between IHE institutions globally. Included in this type of endeavor are the UN Academic Impact (UNAI), Model UN (MUN), and UN internship programs, as well as UN sponsored faculty chairs and curriculum-building projects.

UNAI, launched in 20I0, aims to link universities more closely with the UN, promote UN objectives, and create a global university network for peace and development. Nearly I,००० schools worldwide have joined, agreeing to create new programs aligned with UN principles related to education, global citizenship, sustainable development, and conflict resolution. Examples of these include the Ukraine's national university pre-school for underprivi- 
leged children and Cornell University's recently launched International Architecture and Rural Development major. Almost as old as the UN itself, MUN is a UN-supported, externally managed educational simulation of UN experience and academic competition for university and high school students. MUN teaches UN principles and protocol, develops research and debate skills, and broadens participant knowledge on diplomacy, international law, and global politics. MUN conferences with thousands of participants are held annually throughout the world. UN internships, available through the UN Secretariat, specialized agencies and regional centers for graduate students with majors related to UN topics, are another component of UN IHE programming. Students offer unpaid labor in exchange for work experience and academic credit within a branch of the UN. UNAI, MUN, and the UN internship programs all seek to educate university students on UN activity, objectives, and careers, ideally fostering more socially responsible youth.

Other UN IHE non-degree programs include collaborative faculty exchange and curriculum development. The UNESCO university twinning and networking scheme, for instance, promotes a series of faculty chair positions and networking communities within universities around the world. This program involves 650 institutions in over 120 countries and drives higher education and research capacity building through sponsorship of exchange opportunities in areas related to UNESCO fieldwork-education, sciences, culture, and communication. Additionally, several other UN agencies with expertise, information, and educational experience in particular areas are beginning to partner with universities on projects that broaden curricula. Examples include the International Anti-Corruption Academy (IACA- a UN Office on Drugs and Crime-INTERPOL project that offers a broad professional training curriculum and executive graduate course in Anti-Corruption Studies) and the UN Food and Agriculture Organization's guides for food security, statistical analysis, and online curriculum development. These capacity development services have been widely accessed by developing country institutions.

\section{Knowledge Diplomacy Potential}

UN international higher education knowledge diplomacy activity spans a broad mix of programming and is still relatively new. Nevertheless, regarding its potential for advancing UN and member state ideals and goals, several observations can be made. The UN does not have higher education delivery in its mandate or experience base; therefore, any UN university program is dependent on host government endowments and external resources. This is expensive and sometimes unsustainable. Also, the UN's degrees are not yet prominently recognized and its university-oriented research is not its most widely disseminated and utilized product, which raises questions of cost-benefit justifiability.

UN IHE endeavors yield most when tied to projects and issues immediately relevant to national economies, academic institutions, and professionals rather than to UN-generated agendas. Thus, the non-degree granting UN brokering of IHE professional and information exchange seems a more natural and cost effective fit. Countries on both sides of the equation have embraced UN provision of funding, networking, information, documentation, and publication for IHE exchange and there is significant room for expansion of these activities. That UN information, experience and infrastructure can be beneficial to international higher education programs is certain; less clear is how the UN can best package and market these resources for optimal impact.

\section{The Changing Landscape of International Education Research}

\section{Douglas Proctor}

Douglas Proctor is a PhD candidate in International Higher Education at the University of Melbourne, Australia.E-mail: douglas.proctor@ ieaa.org.au. A full report presenting analysis of 2011-2013 data from the IDP Database of Research on International Education, and an infographic presenting key 2011-2014 trends, are available on the International Education Research Network web site at www.ieaa.org.au/iern.

$C$ iven the uneven landscape of higher education around $\checkmark$ the world, it is not surprising that research on international higher education has its own topography. It is concerning, however, that large areas of the research terrain in international education have yet to be charted.

A recent analysis of data from the IDP Australia Database of Research on International Education has shown that research on international education is predominantly focused on the Anglophone world-with over 53 percent of all research published between $20 \mathrm{II}$ and 20I3, looking at English-speaking countries. Similarly, research on international education is strongly associated with the higher/ postsecondary education sector, despite the multisector nature of international education itself. Students are also the predominant focus of this research, rather than the faculty who teach them, the industry and business sectors that subsequently employ them, or the broader internationalization agendas of their institutions. 